\title{
Systems Design
}

\section{Ethical Tools for Ethical Change}




\section{Information Systems Series}

Series Editor: Professor 1.O. Angell

Computer Security Within Organizations

Adrian R. Warman

Developing Information Systems

Concepts, Issues and Practice

Chrisanthi Avgerou and Tony Cornford

Effective Systems Design and Requirements Analysis

The ETHICS Approach

Enid Mumford

General Systems Theory

An Introduction

Lars Skyttner

Information in Action

Soft Systems Methodology

Lynda Davies and Paul Ledington

Information Systems Management

Opportunities and Risks

Ian O. Angell and Steve Smithson

Ourselves and Computers

Difference in Minds and Machines

Aart Bijl

Systems Design

Ethical Tools for Ethical Change

Enid Mumford

Understanding Information

An Introduction

Jonathan Liebenau and James Backhouse 


\title{
Systems Design \\ Ethical Tools for Ethical Change
}

\author{
Enid Mumford
}




\section{a}

(C) Enid Mumford 1996

All rights reserved. No reproduction, copy or transmission of this publication may be made without written permission.

No paragraph of this publication may be reproduced, copied or transmitted save with written permission or in accordance with the provisions of the Copyright, Designs and Patents Act 1988, or under the terms of any licence permitting limited copying issued by the Copyright Licensing Agency, 90 Tottenham Court Road, London W1P 9HE.

Any person who does any unauthorised act in relation to this publication may be liable to criminal prosecution and civil claims for damages.

First published 1996 by

MACMILLAN PRESS LTD

Houndmills, Basingstoke, Hampshire RG21 6XS

and London

Companies and representatives

throughout the world

ISBN 978-0-333-66946-4

ISBN 978-1-349-14199-9 (eBook)

DOI 10.1007/978-1-349-14199-9

A catalogue record for this book is available from the British Library.

$\begin{array}{rrrrrrrrrr}10 & 9 & 8 & 7 & 6 & 5 & 4 & 3 & 2 & 1 \\ 05 & 04 & 03 & 02 & 01 & 00 & 99 & 98 & 97 & 96\end{array}$




\section{Contents}

Preface vi

1 The past and the present 1

2 Systems designers and the ethics of design 15

3 Systems design in an unstable environment 30

4 An ethical pioneer: Mary Parker Follett 46

5 An ethical approach: socio-technical design 64

6 Designing for freedom in the ethical company 79

7 Designing for the future 99

$\begin{array}{ll}\text { Introduction to the appendices } & 108\end{array}$

$\begin{array}{lll}\text { Appendix A } & \text { The ETHICS method } & 110\end{array}$

$\begin{array}{lll}\text { Appendix B Exercise in socio-technical design } & 117\end{array}$

$\begin{array}{ll}\text { Index } & 165\end{array}$ 


\section{Preface}

This book is about making choices that take account of the needs and interests of a particular group of people, namely the employees of companies. The 'choice' situation that is discussed is when firms are making system changes, particularly changes that include technology. The author hopes that interested readers of the book will include systems designers, and other change agents, whose decisions can influence what is changed and how it is changed.

When major change is being introduced by a company there are usually a number of stakeholders. These include the shareholders who hope for increased profits, the senior managers who hope for performance awards and promotion, the customers who hope for better and cheaper products, the suppliers who hope that their business will increase as the company prospers and the employees who have to suffer the changes. At present the interests of shareholders, senior managers, customers and suppliers seem to be reasonably well taken care of, through increased dividends, performance-related pay, cost reductions and increased orders. The group that is less fortunate and, indeed, sometimes placed in a victim role, is the lower level management and non-managerial employees. They are experiencing loss of employment, greater insecurity and a deterioration in working conditions through longer hours, tighter controls and greater stress. The traditional friends of these employees seem no longer able to operate in a protective role. Trades unions have been seriously weakened by government policies, and the traditional personnel manager, who often mediated the boundary between employee and senior management interests, has changed into a bottomline focused human resources manager.

American business books tell us that we live in volatile and uncertain times. To survive, companies must drastically restructure so that they become flatter and more flexible. One of the buzz phrases for this reorganization is business process re-engineering. The books also tell us that this volatile change process will continue indefinitely. But this is a hypothesis, and it remains to be seen whether it will prove to be correct. Biology suggests that continual change is unusual in nature. Most species develop through long periods of stability, interrupted by short periods of change.

The theory behind this book is that rapid change is usually followed by stability, and businesses and their employees both profit from this. Although change must be managed effectively, at the same time it is important to have strategies in place that encourage stability.

A great deal of what is happening in industry today would have been regarded as undesirable and unethical twenty years ago. Many of the UK's best companies, for example, Cadbury's, Lever Brothers and Bibby's, had Quaker owners and prided themselves on the security and good working conditions that 
they could offer their staff. They looked after their employees, with Cadbury's and Lever Brothers even providing their staff with high quality housing on attractive estates. They respected trades unions and were able to work with them on an amicable basis. They were successful companies that maintained their stability even when faced with major change.

This book presents a different hypothesis to the American one of continuous and chaotic change to which firms must respond or they will perish. It suggests that we will soon see some countervailing forces exerting an influence on company policies. One of these will be the labour market which, in Britain, has always been short of specialist skills. Firms will start competing for the increasing amount of skilled labour they require as technology advances and, to secure this, they will offer contracts and conditions of work that employees see as attractive.

A second countervailing force is likely to be the re-emergence of the trades unions in a new form. Like the German trades unions, they will be happy to collaborate with management in working hard for commercial success, but at the same time they will require employers to provide their members with job security and a good quality of working life. A new industrial relations climate will then cause ethical policies, practice and behaviour to become of renewed importance. Many companies wish to behave ethically and to provide job satisfaction and a good quality of working life for all their employees. This objective can be assisted by the kinds of decisions that are taken when change is introduced.

Taking an ethical position is never easy and everyone has to decide for themselves what is right or wrong, act in accordance with their decisions and accept the consequences of their conduct. Often there are moral dilemmas to be faced and a choice has to be made between a number of moral principles that may seem equally important. The two moral principles that most influence this book are ones that the author regards as important and, over the years, has been trying to contribute to in her own work. They are quality of working life and freedom in work. Quality of working life encompasses good working conditions, job security, opportunities for learning and personal development and adequate financial and other rewards. They are material things that the good company will provide. Freedom in work is the opportunity to exert influence, take decisions, make choices and to be regarded as a partner rather than as a subordinate.

The author has chosen to focus on how systems designers, and change agents, can assist the creation of this quality of working life and freedom because their roles as innovators place them in an influential position. The ethical position they take can have a major influence on the work experience of others. She also believes that in today's business world the interests of all stakeholders can be facilitated by the provision of these ethical conditions. Today's companies need creative, responsible employees able to solve problems, make choices and implement decisions. This is also what the modern worker and manager wants and so the interests of business and staff increasingly coincide. The introduction 
of technology provides particular opportunities for making ethical choices, as it can degrade or enhance the quality of working life, depending on the design route that is selected. It also presents new problems, the consequences of which cannot always be foreseen.

Computer professionals and other change agents have considerable power over the quality of working life and the freedom of other employees. The ethical position that they take can have a major impact on the work experience of others. 